\title{
Review of good agricultural practices for smallholder maize farmers to minimise aflatoxin contamination
}

\author{
F. Xu ${ }^{1 *}$, R.C. Baker ${ }^{1}$, T.B. Whitaker ${ }^{2}$, H. Luo ${ }^{1}$, Y. Zhao ${ }^{1 *}$, A. Stevenson ${ }^{1}$, C.J. Boesch ${ }^{3}$ and G. Zhang $^{1}$ \\ ${ }^{1}$ Mars Global Food Safety Center, 2 Yanqi North Road, Yanqi Economic Development Zone, Huairou, 101407 Beijing, \\ China P.R.; ${ }^{2}$ North Carolina State University, P.O. Box 7625, Raleigh, NC 27695-7625, USA; ${ }^{3}$ Food Systems and Food Safety \\ Division, Food and Agriculture Organization of the United Nations (FAO), Viale delle Terme di Caracalla, 00153 Rome, \\ Italy; xxu1022@163.com; yueju.zhao@effem.com
}

Received: 6 January 2021 / Accepted: 10 September 2021

(c) 2021 Wageningen Academic Publishers

\begin{abstract}
OPEN ACCESS CC
REVIEW ARTICLE

Abstract

Maize is consumed world-wide as staple food, livestock feed, and industrial raw material. However, it is susceptible to fungal attack and at risk of aflatoxin contamination under certain conditions. Such contamination is a serious threat to human and animal health. Ensuring that the maize used by food industry meets standards for aflatoxin levels requires significant investment across the supply chain. Good Agricultural Practices (GAP) form a critical part of a broader, integrated strategy for reduction of aflatoxin contamination. We reviewed and summarised the GAP of maize that would be effective and practicable for aflatoxin control within high-risk regions for smallholder farmers. The suggested practicable GAP for smallholder farmers were: use of drought-tolerant varieties; timely harvesting before physiological maturity; sorting to remove damaged ears and those having poor husk covering; drying properly to $13 \%$ moisture content; storage in suitable conditions to keep the crop clean and under condition with minimally proper aeration, or ideally under hermetic conditions. This information is intended to provide guidance for maize growers that will help reduce aflatoxin in high-risk regions, with a specific focus on smallholder farmers. Following the proposed guidelines would contribute to the reduction of aflatoxin contamination during pre-harvest, harvest, and post-harvest stages of the maize value chain.
\end{abstract}

Keywords: Aspergillus, maize production chain, smallholder farmers, practical practices.

\section{Introduction}

\section{Why focus on aflatoxins?}

Aflatoxin is by far the most toxic of the eight primary mycotoxins and impacts both human and animal health (Liu et al., 2020). Aflatoxins $\left(B_{1}, B_{2}, G_{1}, G_{2}\right)$ are naturally occurring toxins produced by certain fungi, most importantly Aspergillus flavus and Aspergillus parasiticus (Bankole et al., 2004; Erdogan, 2004; Pascale et al., 2020). Aflatoxins occur most frequently in dry stress when crops are near maturity, or when high moisture is present during harvest, or when crop drying, and storage conditions are inadequate. Countries in latitudes between $40^{\circ} \mathrm{North}$ and $40^{\circ}$ South are susceptible to aflatoxin contamination (Strosnider et al., 2006). Thus, sub-Saharan Africa, South Asia, and Southeast
Asia are regions of high potential exposure to aflatoxins (Strosnider et al., 2006). Parts of the Americas also have a high intake of aflatoxins posing a particular challenge in the tropics, subtropics and the southern United States (Bunnel and Harvey, 2020; Zuber et al., 1976).

Aflatoxins mainly occur in crops in tropical regions and contaminate a wide variety of food and feed crops and products, including maize (corn), peanuts/groundnuts, and other crops such as sorghum, cassava, macadamia nuts, paprika, melon seed, sesame, rice, yam chips, and chili (Wild and Gong, 2010). A recent report by the World Bank estimates that aflatoxin consumption causes 90,000 cases of liver cancer a year (Jaffee et al., 2018). For this reason, many countries have placed strict limits on the amount of aflatoxin that can be present in food commodities 
and animal feed. Aflatoxin is one of the most regulated mycotoxins globally. Nevertheless, there is wide variation in maximum limits (ranging between 1 to $50 \mu \mathrm{g} / \mathrm{kg}$ ) depending on the country and regulated material (Anukul et al., 2013). Varying regulations and the difficulty for operators along the value chain to comply with necessary control measures are a reason for many rejections and impact trade volumes.

\section{Impact of aflatoxin contamination on maize for smallholder farmers}

About two-thirds of 3 billion rural people from the developing world live in about 475 million small farm households (Rapsomanikis, 2015). In these countries, smallholder farmers produce about $80 \%$ of food (FAO, 2004; Suleiman and Rosentrater, 2015). Aflatoxin contamination is a global food safety issue, especially in these regions. Lewis et al. (2005) reported that contamination of homegrown maize with aflatoxins ranged from more than 20 to over $1000 \mu \mathrm{g} / \mathrm{kg}$ in rural Kenya in April of 2004, resulting in 317 reported illnesses and 125 deaths. As a result, aflatoxin contamination of homegrown maize presents a significant threat to the health of rural and urban consumers, who are dependent on maize as their staple crop (Azziz-Baumgartner et al., 2005; Daniel et al., 2011; Mahuku et al., 2019; Suleiman and Rosentrater, 2015). Aflatoxin-contaminated maize can also cause economic loss due to low quality/yield (Catholic Relief Services, 2018). Thus, controlling the conditions that result in growth of Aspergillus and production of aflatoxins at the farm level will improve food safety and contribute to improved food security, especially for those who are dependent on maize, such as smallholder farmers.

Aflatoxigenic fungi, A. flavus and A. parasiticus, may invade maize pre-harvest, at harvest time, during postharvest handling and during storage under unsuitable temperature and humidity conditions (Bryden, 2012; Probst et al., 2014). Pre-harvest infection and contamination of maize by Aspergillus is favoured by plant stress factors such as high temperature, drought, insect damage and low soil fertility (Bruns, 2003; Kaaya et al., 2005; Mutunga et al., 2017; PDNA, 2012). The residual inoculum could result in further accumulation of aflatoxin during storage if conditions are favourable for aflatoxin production (Hell et $a l ., 2008)$. Therefore, a series of measures of prevention and control at these stages would have an impact on preventing contamination with aflatoxins along the maize value chain.

\section{Importance of applying good agricultural practices of maize}

Maize (Zea mays L.) is one of the main cereals used as a source of food, forage and for processed products in industry. World production of maize is around 790 million tons and it is a staple food providing more than one-third of the calories and protein in some countries (Chulze, 2010). Since maize is the dietary staple in many developing countries, contamination of maize grain with aflatoxin has been a major issue in these countries (Lewis et al., 2005). Farms in these countries are generally of small size and run traditionally. Under this scenario, aflatoxin contamination of maize presents a significant threat to the health of smallholder farmers, who are dependent on maize as their staple (Mahuku et al., 2019). Good Agricultural Practices (GAP) as broadly defined, 'applies available knowledge to addressing environmental, economic and social sustainability for onfarm production and post-production processes, resulting in safe and healthy food and non-food agricultural products' (FAO, 2003). Appropriate adoption and monitoring of GAP help improve the safety and quality of food and other agricultural products. In addition, GAP provide the added benefit of increased yield and reduced overall post-harvest losses, making it a double win for smallholder farmers, and greatly increasing incentivization and chances of adoption, under the right development models. A multiplicity of GAP codes, standards and regulations have been developed in recent years by the food industry and producer organisations, and by governments and NGOs, aiming to codify agricultural practices at the farm level for a range of commodities (Philippine National Standards, 2008). Their purpose includes fulfilment of trade and government regulatory requirements regarding food safety and quality.

\section{Impact of climate change}

Aflatoxin-producing Aspergillus species are well adapted to warm and dry climatic conditions (Cotty and JaimeGarcia, 2007). Modelling of interactions between the host plant and environment during the growing season can enable quantification of aflatoxin risk and its potential management (Boken et al., 2010; Chauhan et al., 2008). Recent studies have shown that there is a direct relationship between the relative gene expression of Aspergillus sp. and aflatoxin production under different environmental conditions (Medina et al., 2014).

Changing weather patterns are likely to affect infection of maize with Aspergillus and resulting aflatoxin contamination (Battilani et al., 2016). For example, aflatoxin contamination tends to increase when there are drought periods and high temperatures during the pre-flowering stage, followed by heavy rains at harvest (Liu et al., 2016; Massomo, 2020; Njeru et al., 2019). The prevailing global climate change increases aflatoxin risk, especially in tropical and subtropical regions (Joutsjoki and Korhonen, 2021).

Adaptation to climate change will require appropriate approaches to management of aflatoxin (Thornton and Herrero, 2015). Aflatoxins occur most frequently under conditions where dry weather prevails, but high moisture is present during harvest and drying (Magan and Aldred, 2007). Thus, rapid drying of harvested maize to a safe 
moisture content within two days can reduce the risk of Aspergillus growth and subsequent aflatoxin contamination (Magan and Aldred, 2007). Moreover, reducing tillage, expanding crop rotations and planting cover crops have proven to be good practices for adaptation to climate change (https://tinyurl.com/46y4dnp2).

Smallholder farmers dependent on rain-fed agriculture are experiencing the effects of climate change (Nyang'au et al., 2021). It was reported that a decrease of $10 \%$ in aggregate yields of maize could occur in smallholder rain-fed farming systems in Africa and Latin America by 2055. The major agricultural practices adopted by farmers to adapt to climate change in these areas included diversification of crops, change of planting time and crop rotation/mixed cropping (Nyang'au et al., 2021).

\section{Importance of good agricultural practices for smallholder farmers}

In developed countries levels of aflatoxins in different food commodities are strictly regulated (van Egmond and Jonker, 2008). However, in some developing countries, for example in Tanzania, strict control is difficult for widely scattered smallholder farmers who grow and consume their maize (Massomo, 2020). It is very important to identify practical GAP that can be easily adopted by smallholder farmers to prevent aflatoxin contamination of maize at the farm level. This review will summarise the current agricultural practices specific for smallholder famers and suggest costeffective GAP targeting aflatoxin control. Smallholders were the primary target beneficiaries under consideration, however many of these GAP could likewise be applied on larger farms and by different value chain actors.

\section{Agricultural practices of maize for smallholder farmers}

The traditional maize production chain for smallholder farmers is shown in Figure 1. It separates into pre-harvest, harvest, and post-harvest stages. The pre-harvest stage includes pre-planting, planting, and after-planting steps. The harvest stage includes harvesting, sorting, de-husking and drying of cobs. The post-harvest stage includes shelling, drying the kernels and storage. Aflatoxigenic fungi can infect maize throughout the production chain, thus agricultural practices that can reduce aflatoxin contamination should be undertaken throughout the process.

\section{Pre-harvest practices}

Good pre-harvest practices are critical for minimising aflatoxin contamination since fungal infection starts at this stage (Cleveland et al., 2003; Mahuku et al., 2019). Several control strategies for reducing aflatoxin contamination in crops have been investigated, including management/

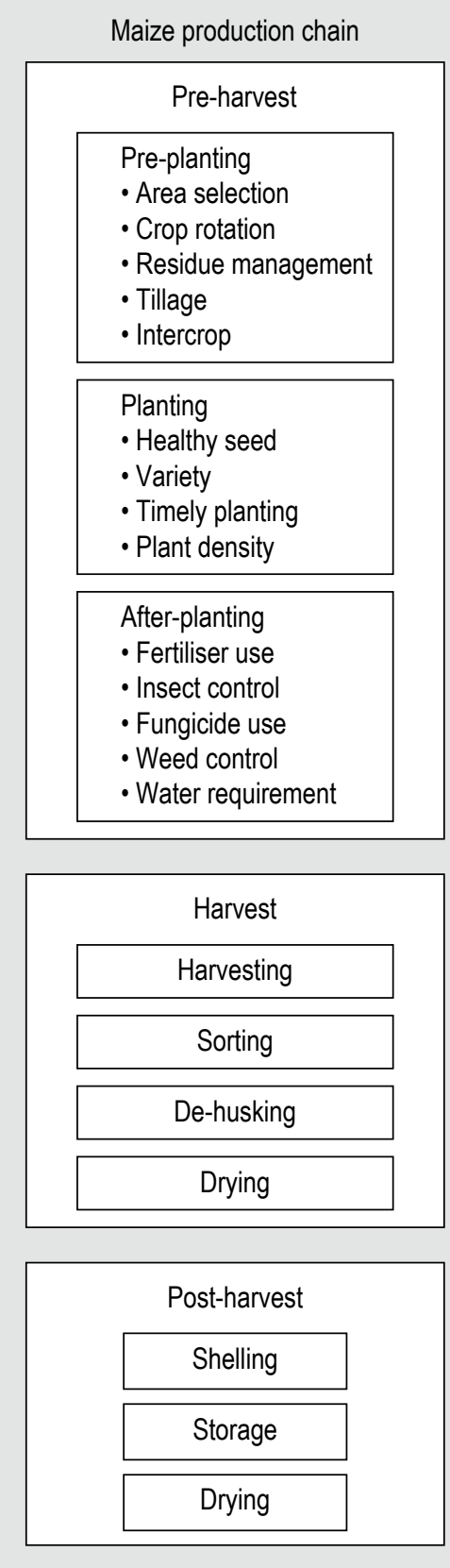

Figure 1. Overview of maize production chain for smallholder farmers.

prevention of pre-harvest drought stress, breeding programs for heat and pest resistant crop varieties and assessing potential biocontrol agents (Spanjer, 2019).

Environmental factors that favour A. flavus infection in the field include high soil and/or air temperature, drought stress, nitrogen stress, crowding of plants and conditions that aid the dispersal of conidia during silking (Diener et al., 1987). Factors that influence the incidence of fungal infection include the presence of invertebrate vectors, grain damage, inoculum load, substrate composition, fungal infection levels, prevalence of toxigenic strains and 
microbiological interactions (Horn, 2003). Crop rotation and management of crop residues also are important in controlling A.flavus infection in the field (Hell et al., 2008).

Tillage practices, crop rotation, fertiliser application, weed control, late season rainfall, irrigation, wind, and pest vectors can all affect the source and level of fungal inoculum maintaining the disease cycle in maize (Diener et al., 1987). The likelihood of aflatoxin contamination increased when maize was intercropped with cowpea (Sétamou et al., 1997). In Africa, crops are cultivated under rainfed conditions with low levels of fertiliser and little or no pesticide application. These conditions promote A. flavus infection of stressed plants, and any action taken to reduce the probability of silk and kernel infection will reduce aflatoxin contamination (Hell et al., 2008). Preharvest management of aflatoxin contamination is vital to maintain contamination levels below economically feasible and legislated thresholds.

Agricultural practices adopted by farmers for raising maize yield can also reduce the spread and survival of fungi in the field as well as plant susceptibility, and thus mitigate aflatoxin contamination of maize (Liu et al., 2016).

\section{Proper production area}

Strategies aiming to minimise aflatoxin should start from the beginning of production to prevent contamination under field conditions, thus a cultivation environment suitable for maize should be chosen. Production areas must always be kept clean. A one to two-month fallow period should be observed before planting if possible (Thai Agriculture Standard, 2010). Critical factors worth evaluation include soil type, soil condition and the availability of viable spores (Horn, 2003). Kaaya et al. (2006) demonstrated that areas with high humidity resulted in higher aflatoxin levels in maize samples compared with dry areas.

\section{Crop rotation}

Crop rotation (growing different crops sequentially) can improve soil health and enhance soil nutrients, reducing plant stress. Mono-cropping of maize could increase the risk of high aflatoxin levels (Demissie, 2018). Incorporating crop rotations will influence both the quantity of Aspergillus in soils and the average aflatoxin producing potential of Aspergillus communities (Jaime-García and Cotty, 2006). Inclusion of non-host crops into the rotation will help control Aspergillus. For example, rotation of legumes crops (cowpea, soybean) with maize can help to break pest and disease cycles and improve soil fertility (Abbas et al., 2012; Matocha and Richardson, 1990). Moreover, the rotation of maize with nonhost crops can effectively reduce plant residues that could allow build-up of inoculum (Jirak-Peterson and Esker, 2011). Rotation schemes may vary geographically based on the local environment or consumption requirement. For example, double cropping has been one key factor to increase the yield of mature maize in Brazil. This combination of planting two crops in a field in the same year, soybean in the rainy season, and maize in the dry wintertime, has expanded the production of local maize (Logrieco et al., 2021).

\section{Residue management}

Fungal spores remain dormant in the soil between crops and from year to year, present in layers of infected crop residues (Hell and Mutegi, 2011). Residue management is critical for reducing the risk of aflatoxin contamination. Previous crop residue on the soil surface can be reduced by various measures including ploughing (Olanya et al., 1997). However, residue management does increase the labour requirements of smallholder farmers. Proper management of the maize residue by removing or burying helps to collapse the chain of fungal infection or eliminate fungal spores, leading to a healthier agricultural ecosystem (Blandino et al., 2008; Liu et al., 2016).

\section{Tillage}

Proper soil aeration regulates the availability of water to the crop. Deep tillage has been observed to improve the soil structure and enhance crop vigour (Diaz-Zorita, 2000). This can lead to a significant reduction in infection by the aflatoxin producing fungi. Adapted tillage methods have been identified, such as breaking the hardpan specifically where seeds will be planted, achieve both reduction of drought stress in the maize as well as minimising tillage (IIRR and ACT, 2005).

\section{Intercropping}

Intercropping is the planting of two or more crops simultaneously on a given piece of land. This practice produces higher yield by making use of resources or ecological processes, whilst restraining the growth of weeds (Liebman and Dyck, 1993). Maize grown intercropped with legumes, such as cowpea, beans, etc., tended to have lower aflatoxin than maize grown as a sole crop, since this may improve the amount of nitrogen in the soil (Mutiga et al., 2014). In maize farming this agronomic practice can include three components: maize, Desmodium legume as the intercrop between maize rows, and Bracharia or napier grass (Pennisetum purpureum) as the border crop planted around the plot.

\section{Breeding varieties}

If the maize variety is not resilient it may be vulnerable to drought, insects, pathogens, etc. (Brown et al., 2003, 2013; Chen et al., 2001; Menkir et al., 2008). Droughtresistant varieties should be used if they are available locally. Alternatives include varieties or hybrids that are adaptable 
to the locality and approved by the local country as seed material. Several screening tools have been developed and used to facilitate maize breeding for developing germplasm resistant to fungal growth and/or aflatoxin contamination (Brown et al., 2003). Sources of resistance to Aspergillus infection and aflatoxin contamination in maize have been identified, but commercial hybrids have not been developed. This is largely due to the difficulty in finding elite lines that maintain high yields and resistance within multiple environments (Clements and White, 2008). Brown et al. (2003) tested aflatoxin resistance in 36 inbred maize lines that were selected in West and Central Africa for moderate to high resistance to maize ear rot. More than half the inbred lines accumulated aflatoxins at levels as low as, or lower than, the resistant US lines. Six tropical maize germplasm lines with resistance to aflatoxin were registered by the same research group in 2008 (Menkir et al., 2008), so that locally adapted hybrids can be developed. Many new biotechnology strategies such as RNA interference, microarray, whole genome sequencing, RNA-sequencing, proteomics, metabolomics have been widely used to deepen understanding of resistance mechanisms and identify genes, proteins, and pathways involved during host-pathogen interactions for aflatoxin contamination in maize. These approaches would allow for the deployment of both conventional and modern breeding tools to facilitate the development of aflatoxin-resistant maize varieties, which reduce the incidence of fungal infection, restrict the growth of aflatoxigenic fungi, or prevent aflatoxin accumulation (Soni et al., 2020).

\section{Optimal planting time}

Planting at an optimal time in good soil conditions is the foundation for successful maize production, and this practice assists in reducing the incidence of aflatoxin contamination in the field (Bruns, 2003). Maize planting (and maturation time of the selected variety) is suggested to be carefully planned to avoid high temperatures and drought stress during seed development and maturation (Abbas et al., 2009). Early planting can be very beneficial for regions with water stress. Wet periods during early flowering should be avoided if possible (Eeckhout et al., 2013). Cultivation of maize in the rainy season, as occurs by necessity in rain-fed systems in many parts of Africa, can lead to an increase in aflatoxin accumulation, particularly if the plants are treated with low levels of fertiliser or with minimal amounts of pesticides. Action to interrupt the probability of silk and kernel infection will reduce aflatoxin contamination (Diener et al., 1987).

\section{Plant density}

Overcrowding of plants may lead to humid and warm conditions which favour insect, pathogen and disease development and it can also result in reduced yield due to competition for soil nutrients and sunlight (Blandino et al., 2008). It should be noted that high plant density becomes an important risk factor under drought stress (Abbas et al., 2012). By maintaining the recommended row and intraplant spacing for the species or varieties, overcrowding can be avoided. Seed and breeding companies, as well as extensionists, can provide useful information related to plant spacing. Hybrid crops and inbred lines of maize had significant effects on the severity of ear rot and the level of aflatoxins (Balconi et al., 2014; Blandino et al., 2017). Maize yield and degree of interplant competition were affected by variations in plant density for the specific hybrids (Sangoi et al., 2002). In addition to breeding, it is therefore important to establish planting plans that guarantee optimal numbers to reduce maize contamination by fungi and aflatoxins.

\section{Fertiliser application}

Fertilisation is an important practice for aflatoxin control. However, nutrient deficiencies or over-fertilisation, particularly with nitrogen, may lead to greater susceptibility to insect pests and diseases (Tubajika et al., 1999). The appropriate application of fertilisers and soil additions, such as lime (calcium), animal manure, and compost, can minimise plant stress, especially during seed development, by assuring an adequate soil $\mathrm{pH}$ and plant nutrition (Mutunga et al., 2017). This can reduce aflatoxin contamination. While application of the fertiliser will introduce additional cost for smallholder farmers, maize cultivation without fertilisation does not bring good economic results. Mineral fertilisers can of course be replaced with natural fertilisers, which are often available for smallholder farmers.

There was a strong correlation between knowledge of maize ear rot and knowledge of aflatoxin for smallholder farmers. Levels of aflatoxin were significantly and positively related to the use of diammonium phosphate (DAP) fertiliser at planting (Njeru et al., 2019). Thus, the use of DAP fertiliser is considered one of the critical agronomic factors in maize production (Ndemera et al., 2018).

\section{Insect control}

Insects propagate fungi and cause damage that allows the fungi to access the maize, increasing the chances of aflatoxin contamination (McMillian et al., 1985; Sétamou et al., 1997). The maize borer, Ostrinia nubilalis, the maize earworm, Heliothis zea, and the fall armyworm, Spodoptera frugiperda, have been identified as the major insects implicated in A. flavus infection and subsequent aflatoxin contamination of preharvest maize (Widstrom, 1979; Windham et al., 1999). When insect damage occurred simultaneously with favourable climatic conditions, such as drought stress and high temperature, high aflatoxin concentrations were usually found in maize grains (Magagnoli et al., 2021). Appropriate insect management 
techniques will reduce formation of holes and damage to the cobs which, in turn, will reduce the entry points for the fungus (Hell and Mutegi, 2011; Sétamou et al., 1998). Thus, the application of registered insecticides especially when drought and heat stress frequently occur during the reproductive stages of the plants, can mitigate the risk of fungal growth. However, smallholder farmers often lack access to appropriate insecticides, proper information or the means to properly and safely apply them, so health risks must also be taken into consideration (further addressed in the paragraph below on fungicide application). Pests and diseases must be controlled early enough to avoid epidemics that can lead to extreme plant stress, quality damage, and economic losses (Hell and Mutegi, 2011; Higley and Pedigo, 1993). The incidence of the insect borer Mussidia nigrivenella, was positively correlated with aflatoxin contamination of maize samples collected in Benin (Hell et al., 2008). The chance of insect damage and aflatoxin contamination increases when loose-husked maize hybrids are used (Dowd, 2003).

\section{Fungicide application}

Air dispersal of fungi is associated with infection of maize (Anitha et al., 2019). Fungal infection can occur through airborne spores in the field during pre-harvest or during storage. The fungus usually colonises the silk and kernels when the silk is cut or the cob is damaged due to excessive drought (Amaike and Keller, 2011). Keep plants healthy to avoid fungal infection. Fungicides currently remain our most potent weapon against fungal maize pathogens (Steinberg and Gurr, 2020). However, no chemical control against Aspergillus is authorised in maize to date (Ferrigo et al., 2019). Fungicides have not been widely used for aflatoxin management in maize. Fungicides have been shown to be effective for controlling deoxynivalenol in small grain cereals, so this success has promoted similar research in maize (Logrieco et al., 2021). Several azolebased fungicides have proved to effectively reduce $A$. flavus growth and aflatoxin production, but stimulation of aflatoxin production was found under particular conditions and low-dosage treatments (Ferrigo et al., 2019; Mateo et al., 2017). Azole-based fungicides have potential to be included in a multi-strategy approach to control Aspergillus infection in maize, in the context that sustainable use of pesticides is ensured (Ferrigo et al., 2019).

\section{Pesticide misuse considerations}

In the case of smallholder farmers in developing countries, the capacity of the agricultural system to inform and support the proper and safe application of the correct pesticides (insecticides and fungicides) is greatly lacking. This must be a critical consideration before pesticides are recommended as an approach. A meta-analysis by
Boedeker et al. (2020) aimed to check the World Health Organization's 1990 estimate that one million global pesticide (fungicide and insecticide) unintentional, acute pesticide poisonings (UAPP) occur annually; the study estimated that approximately $44 \%$ of farmers globally suffer from UAPP, or $\sim 385$ million with 11,000 fatalities. Without substantial and sustained capacity building in many developing country agricultural systems, targeted to key actors, other GAP methods are much safer overall in those systems as they exist currently. The GAPs recommended in this review include these types of important alternatives, with developing country smallholder farming systems as the key focus. For example, hermetic bags and cocoons obviate the need for pesticide application during storage; some of these have been developed with slow-release safe insecticide (Paudyal et al., 2017), gaining regulatory approval by developing country governments such as Ghana, and effectively bringing pesticides safely into the smallholder farming system without placing the responsibility of appropriate and safe application in the hands of the smallholder farmers and input suppliers. In another example of a possible alternative, Zhang et al. (2016) estimated that wider adoption of GM crops which reduce pesticide use in China and globally may increase farmer health. While pesticides are an important tool to consider in addressing mycotoxin contamination, a holistic and sustainable approach to effectively empower proper use in national systems by resource-poor farmers must be a strong part of any initiative recommending this strategy.

\section{Weed control}

Timely control of weeds should be undertaken to avoid them competing with the crop. Appropriate weed control measures such as proper land preparation, off-barring at 12 to 15 days after planting (DAP) and/or hilling-up at 25 to 30 DAP should be undertaken (Philippine National Standards, 2008). Care should be taken during cultivation to avoid damage to the plant. Weed control can be done manually with a hoe, bull, tractor, or with an herbicide. Safety considerations around misuse of herbicides are similar to those discussed above.

\section{Water requirement}

An adequate water supply should be maintained, especially at the stage of seed-germination. Irrigation and water management in maize planting could be ranked as one of the top three critical factors (Logrieco et al., 2021). Irrigation systems should be designed to provide sufficient water against drought stress, while the water requirement should also be met to avoid moisture stress particularly during flowering up to the maturation stage. However, excessive moisture increases contamination risk in the crop canopy, since the crop is more susceptible to aflatoxin contamination at these stages (Philippine National 
Standards, 2008). Unfortunately, this is often not readily available as an option to smallholders growing maize in high-risk areas as they rarely have access to irrigation. In these situations, it is suggested to build soil organic matter for greater water retention (Ankenbauer and Loheide, 2017), and breaking the hardpan at the point of seed planting (Farm Input Promotions Africa strategy). Research has proven that aflatoxin levels in maize could be reduced by $99 \%$ when a combination of appropriate irrigation and insecticide were applied, compared to non-irrigated, non-treated maize in the US. Nevertheless, accessibility to irrigation systems and the cost of this combination appears to be challenging for smallholder farmers (Khlangwiset and Wu, 2010; Smith and Riley, 1992).

\section{Practices during harvest}

Reduction of fungal infection during pre-harvest is not enough to prevent aflatoxin contamination. Aflatoxin management must continue at the harvest and post-harvest periods. Practices during harvest can play a key role in preventing or arresting aflatoxin contamination.

\section{Timely harvesting}

Extended field drying of maize could result in serious crop losses during storage and timely harvesting is recommended to combat aflatoxin problems (Borgemeisterab; et al., 1998; Kaaya et al., 2006). An increase of aflatoxins of up to seven times was observed when maize harvesting was delayed for a month in Uganda (Kaaya et al., 2006). Another report noted that aflatoxins in maize increased 4- to 7-fold after 3-4 weeks delay in harvest after maturity (Demissie, 2018). Physiological maturity is approximately 100 to 120 days after planting for yellow maize and 90 to 100 days after planting for white maize (Philippine National Standards, 2008); as another reference, there are varieties of maize in the Northern USA which mature at 80 and 120 days (Ashley, 2021). The exact day depends on the varieties or hybrids. Harvesting of maize at physiological maturity is recommended in low risk regions (Mejía, 2003). Fields with higher risk for aflatoxin formation should be treated differently from those fields with a lower risk. Earlier harvesting is recommended in high-risk regions, as fungal pathogens will have less time to develop and potentially produce aflatoxins (Bruns, 2003; Dovenyi-Nagy et al., 2020; Monda et al., 2020; Udoh et al., 2000).

\section{Proper harvesting techniques}

Harvesting should be completed in the shortest time possible especially during the rainy season. Care must be taken during harvesting to prevent damage, as damage to the cobs permits easy entrance of fungi (Sumner and Lee, 2017). Harvesting of maize with the husk could reduce aflatoxin contamination (Demissie, 2018). Fungal attack occurs during harvest mostly because of dropping and drying cobs on bare ground, allowing easy transfer of the fungus from the soil to the storage facilities (Mutiga et al., 2019). Cobs should not be left to dry in the field on bare soil after harvesting (Massomo, 2020). Field stacking (heaping) does not provide enough aeration for the ears and could lead to colonisation of maize by aflatoxigenic fungal strains (Manu et al., 2019). Thus, harvested products should be collected into clean baskets or onto clean underlayers. Maize ears should not be left in containers for more than 6 hours between harvesting and drying (Sumner and Lee, 2017).

\section{Sorting to remove poor quality ears}

Damaged cobs should not be mixed with healthy ones, to reduce the spread of spores and subsequent infection. Sorting and removing visibly mouldy, damaged, or irregularly shaped cobs and cobs having poor husk covering before storage is an effective method for reducing aflatoxins (Afolabi et al., 2006; Fandohan et al., 2005; Mutiga et al., 2014; Park, 2002; Turner et al., 2005). This was also ranked as an important practice by Logrieco et al. (2021). For example, it has been suggested that maize ears having greater than $10 \%$ ear damage should be removed (Sétamou et al., 1998), although even those with less than $10 \%$ damage can serve as a source of mycotoxigenic fungal inoculum during storage, especially under poor storage conditions. Either simple physical (e.g. manual sorting) for smallholder farmers (Kagot et al., 2019) or flotation and density separation methods for middle/larger scale farmers can be done for sorting purpose (Khlangwiset and Wu, 2010); however, wetting the grains for flotation is not recommended since any fungi present will have ideal conditions to rapidly multiply and produce aflatoxin. It was reported that physical sorting alone has been found to reduce aflatoxin levels by $40-80 \%$ (Kumar et al., 2016). Separate maize ears with poor quality away from the production area.

\section{De-husking}

Manual harvesting is the most convenient and popular method. Extension efforts with smallholder farmers typically recommend that maize ears are suggested to be removed from the plants by hand without husking (Shee et al., 2019). The basis of this recommendation is that the husk will protect the cobs by husk during transportation. Removal of its leafy outer covering can be done manually before drying. This harvesting method can be done quickly and will help protect the kernels from exposure to soil during harvesting, and damage or cracking during harvest and transportation. 


\section{Immediate drying after harvesting}

Aflatoxin contamination can increase 10-fold in a three day period when harvested maize is stored with a high moisture content (Hell et al., 2008). Leaving ears in containers for more than six hours between harvesting and drying can increase risk of aflatoxin accumulation, and drying maize on the cob before shelling is a good practice (Chulze, 2010); the generally accepted recommendation is that harvested commodities should be dried as quickly as possible. The cobs are tougher and can overcome damage brought about by the shelling at this moisture content (Philippine National Standards, 2008). This was ranked as the most important postharvest management action by Logrieco et al. (2021). Achieving this through simple sun-drying is the traditional practices for smallholder farmers. It is advised that cobs should be dried on polyethylene sheets laid on the ground instead of directly drying them on the soil. Alternatively, a range of solar and mechanical dryers have been developed and are already scaling with smallholder farmers in a number of countries. For example, the Feed the Future Innovation Lab for the Reduction of Post-Harvest Loss developed the BAU-STR dryer in Bangladesh, and it now scaling with smallholder farmers (Alam et al., 2020).

\section{Practices after harvest}

Post-harvest strategies are critical in preventing aflatoxin contamination, given Aspergillus' ability to grow and spread during this period (Kamala et al., 2018). Appropriate sorting, drying, and storage techniques can significantly reduce aflatoxin contamination by $63-88 \%$ or more (Unnevehr and Grace, 2013).

\section{Shelling and sorting}

It is important to avoid damage and remove broken kernels during shelling. Care should be taken during manually shelling if that is the only option available to the smallholder farmers. The containers used for the shelled maize should also be clean and dry. Shi et al. (2014) found that removing fines resulted in aflatoxin levels in the removed fines 4650 times that in the cleaned fraction. Although other studies failed to observe significant reduction of aflatoxin by manually sorting out discoloured and broken kernels, they still found reduction of fumonisin (Mutiga et al., 2014), further supporting this as a best practice.

\section{Drying}

Maize should be dried after harvest to halt fungal growth and aflatoxin production during postharvest storage (Hawkins et al., 2005). Natural direct sunlight is the most feasible option for many smallholder farmers for drying their crops, and is the traditional practice. Extensionists often advise that smallholder farmers should dry on polyethylene sheets laid on the ground (however some studies have failed to find that these make a statistical difference in aflatoxin levels, e.g. Bauchet et al., 2020). Farmers should make sure the layers are not too deep when drying the cobs or shelled kernels. Cobs or kernels at the bottom will take longer to dry and high moisture maize is more likely to become contaminated with aflatoxin. Improper drying of cobs leads to retention of moisture. It is imperative to ensure that crops have reached optimal moisture levels within 48 hours after shelling, in order to discourage mould growth and toxin production while in storage (Philippine National Standards, 2008). The moisture content for maize kernels is recommended to be below 13\% (Manu et al., 2019). The measurement of the moisture content of the maize should be determined in a representative sample randomly taken from the whole batch. Clean suitable containers should be used for the dried kernels. It is strongly suggested that dry maize should not be mixed with wet maize or any foreign matter.

However, outdoor sun drying is the traditional method that smallholder farmers can use for reducing the moisture content of maize, so it can be challenging to achieve the safe moisture content in time, potentially favouring fungal infection, and aflatoxin contamination. It is a common practice among farmers that they estimate maize moisture content by puncturing kernels with their thumbnail or biting kernels with their teeth (Liu et al., 2016).

\section{Proper storage}

Proper storage and moisture management have been suggested as critical aflatoxin contamination control interventions (Walker et al., 2018). It should be situated in areas where there is no flooding (Kaaya and Kyamuhangire, 2006). Proper condition should be undertaken and minimally with proper aeration, or ideally under hermetic conditions. Moisture in stored maize should be kept below $13 \%$ to stop the development of aflatoxin (Shepherd, 1999). Maize should not be heaped in stores, unless in appropriate hermetic bags; it should be packed in clean, sealed containers to avoid exposure to excessive moisture and humidity. Maize should be packaged into manageable weights (up to $25 \mathrm{~kg}$ ) in clean containers or bags. The temperature of the stored maize should be checked periodically. Visual checks should also be conducted for evidence of fungal growth and to allow separation of the infested or infected portion. Cleanliness to prevent insect infestation and disease infection should always be maintained. Traditional practice in India is to use the jute bags for storage (Bari et al., 2012). Recent data indicated that it is better to use new jute bags; if this is not possible bags should be cleaned as much as possible and free of aflatoxigenic fungi (Wang et al., 2021). The first-in firstout principle should be followed during storage and use of the maize. 


\section{Practicable good agricultural practices for smallholder farmers}

Based on the reported information specific for smallholder farmers, the following agricultural practices were identified as having high impact on the reduction of aflatoxins: residue management, crop rotation, variety, plant density, fertiliser use, insect control, water requirement in the pre-harvest stage; timely harvesting, proper harvesting techniques, sorting, immediate drying, in the harvest stage; drying and proper storage in the post-harvest stage (Catholic Relief Services, 2018; Demissie, 2018; Hell et al., 2011; ICRISAT, 2016; Mahuku et al., 2019; Sumner and Lee, 2017; Udomkun et al., 2018). Most smallholder farmers indicated that the use of residue management, crop rotation, and irrigation are the most expensive of the potential control methods (Mutiga et al., 2019; Udomkun et al., 2018). Only some farmers accept new production technology such as fertilising and pest control (Semple et al., 1989). Additionally, residue management requires more labour for smallholder farmers. Smallholder farmers are also unwilling to change their manner of crop rotation and decrease plant density (Moswetsi et al., 2017; Udomkun et al., 2018). These changes may need more communication and education with the support of local governments. In summary, the suggested practicable GAP for smallholder farmers in high-risk regions are use of drought resistant varieties, timely harvesting, sorting, drying and proper storage. These GAP provide a balance between impact on aflatoxin prevention and practical feasibility that can help smallholder famers reduce aflatoxin contamination at a farm level in high-risk regions.

\section{Emerging technologies for smallholder farmers}

Biological control using atoxigenic strains of $A$. flavus during preharvest was reported to reduce infection by toxigenic strains (Bandyopadhyay et al., 2016; Cotty and Bhatnagar, 1994; Pitt, 2019). This type of biocontrol was achieved by spreading non-aflatoxigenic $A$. flavus spores onto the field at particular times prior to harvest. It was reported that atoxigenic strains could out-compete endemic, toxigenic strains, thus reducing the aflatoxin levels in kernels (Ehrlich, 2014). Biological control using nontoxigenic fungi, although applied in the field, can reduce aflatoxin contamination for as long as six months postharvest (Khlangwiset and Wu, 2010). The International Institute of Tropical Agriculture (IITA) and the United States Department of Agriculture-Agricultural Research Service (USDA-ARS), as well as local national institutes, successfully adapted and improved this technology for use in controlling aflatoxin contamination in sub-Saharan Africa under the trade name Aflasafe (Bandyopadhyay et al., 2016; Logrieco et al., 2021). Several countries in Africa have registered Aflasafe products (https://aflasafe.com). In
Kenya, Aflasafe is manufactured at a government-owned facility and sells for US\$2.00 per kg (Keyser and Sela, 2020). Reports showed that a single application of Aflasafe two to three weeks before maize flowering can prevent aflatoxin contamination throughout the production process, even when grains are stored. It has been suggested that local atoxigenic Aspergillus strains that potentially competitively exclude aflatoxigenic strains are used where possible, to avoid the introduction of 'foreign' fungi (Khlangwiset and $\mathrm{Wu}, 2010)$. Evaluation of the affordability and costeffectiveness of biological control products needs to be addressed for smallholder farmers (Kagot et al., 2019; Massomo, 2020; Pitt, 2019). The promotion of biological products as a strategy to reduce aflatoxin contamination has raised concerns about potential long-term environmental risks and long-term efficacy in the field conditions (Joutsjoki and Korhonen, 2021; Kagot et al., 2019; Pitt, 2019). Moreover, the allergenic and human health aspects of the atoxigenic strain need to be evaluated (Atehnkeng et al., 2008; Kagot et al., 2019).

During the preharvest stage mechanical technologies, such as soil testing devices, controlled irrigation systems, soil irrigation sensors, and gypsum and fertiliser spreaders, can reduce aflatoxin contamination (Kamau et al., 2018), and all these also help to increase crop yield and net return (Parimi et al., 2018). However, application of these technologies will introduce additional cost, limiting their usefulness for most smallholder farmers.

Shellers can contribute to reduction of aflatoxin contamination by shelling pods faster and keeping them dry. However, in some cases water may be sprinkled onto pods during hand shelling to make them softer, increasing the risk of aflatoxin contamination (Kamau et al., 2018).

For drying, moisture monitoring can be undertaken with a calibrated moisture meter. Alternatively, the DryCard is a new technology developed by the Horticulture Innovation Lab at University of California, Davis targeted at smallholder farmers (Thompson et al., 2017). This uses colour changes to indicate whether the kernels are dried to the safe level (Catholic Relief Services, 2018). For middle/larger scale farmers, mobile grain-drying equipment have been tested in field trials (Hoffmann and Jones, 2018). But these dryers have not been adopted smallholder farmers largely owing to their high investment and operating costs and unattainability (Hoffmann and Moser, 2017; Joutsjoki and Korhonen, 2021). In industrial nations, drying with forced air and supplemental heat is common to control moisture levels. It is reported that at $70^{\circ} \mathrm{C}, A$. flavus infection is significantly reduced compared to that in the maize dried at $40^{\circ} \mathrm{C}$. But this high temperature may potentially reduce seed germination and increase stress cracks (Hawkins et al., 2005; Khlangwiset and Wu, 2010). 
During storage, many farmers store maize in bags, especially polypropylene bags which are not airtight. However, there is evidence that this method of storage facilitates fungal contamination and aflatoxin development (Hell et al., 2000; Udoh et al., 2000). Hermetic storage technologies to prevent weevil damage and subsequent accumulation of aflatoxins have been developed, such as improved hermetic storage bags, Purdue Improved Crop Storage (PICS), and GrainSafe ${ }^{\odot}$ bags (Ben et al., 2009; Murdock et al., 1997; Walker et al., 2018; Williams et al., 2014). The AflaSTOP project determined that PICS bags were the most successful solution for smallholder maize farmers (ACDI/VOCA, 2017; ICRISAT, 2016). The Post-Harvest Loss Innovation Lab (PHLIL) worked with Vestergaard on ZeroFly Hermetic bags - which also contain slow-release insecticide. They are very effective and being scaled in several developing countries.

\section{Challenges}

\section{Risks and contingencies}

Farmers might not be willing or able to change their current paradigms. This could be due to the fear of change and potential impact on family income. In some cases, GAP implementation will increase production costs. Also, limited awareness of the smallholder farmers on risks at all levels and insufficient knowledge on the options to reduce aflatoxin contamination through the production to consumption chain influence their ability to change.

Agricultural practices summarised in this review are mainly focused on high-risk regions, such as sub-Saharan Africa, India, Thailand, and Southeast Asia (Benkerroum, 2020; CAST, 2003; Khlangwiset and Wu, 2010). It is unlikely that there is a single solution for all regions due to different geographic locations and climate.

\section{Suggestions}

Awareness of 'win-win' practices which lead to improvements of yield and aflatoxin reduction, as well as the environment and health and safety of farmers, needs to be raised. If applicable, creating financial incentives to encourage smallholder farmers to adapt these GAP. Communication to, and education of the key stakeholders is imperative. Continued efforts by relevant international and regional agencies (e.g. FAO, World Food Program (WFP), The Partnership for Aflatoxin Control in Africa (PACA), etc.) in collaboration with local government and in partnership with the food business actors and the scientific community will be necessary to educate smallholder farmers on the danger of commercialising and consuming contaminated foods. We can change agricultural practices through education and demonstration, to help them reduce aflatoxin contamination.

\section{Conclusions}

This review summarised the current knowledge of GAP of maize throughout the maize production chain. Practicable GAP to reduce aflatoxin contamination of maize in highrisk areas were identified. These GAP extended across the pre-harvest, harvest, and post-harvest stages of maize cultivation, and were prioritised based on their likely impact on the level of aflatoxin contamination. The five main GAP were: use of drought-tolerant varieties; early harvest before physiological maturity; sorting to remove damaged ears and those having poor husk covering; drying properly; proper storage. This information is intended to provide guidance for maize growers that will help reduce aflatoxin in highrisk regions, with a specific focus on smallholder farmers.

\section{Acknowledgements}

The authors thank Jagger Harvey (Kansas State University), Mark Edge (Bayer), Michael Friend (Intellectual Ventures Lab/Global Good), Samuel K. Mutiga (University of Arkansas), Rebecca J. Nelson (Cornell University), David Priest (Farm Inputs Promotions Africa), Randy Ford (Mars Inc), John Bennett (Mars Inc) and Victor Nwosu (Mars Inc) for their valuable comments/inputs. The authors would also like to thank Peter Markwell for comments that greatly improved the manuscript.

\section{Conflicts of interest}

All authors declare no conflict of interest.

\section{References}

Abbas, H.K., Mascagni Jr, H.J., Bruns, H.A. and Shier, W.T., 2012. Effect of planting density, irrigation regimes, and maize hybrids with varying ear size on yield, and aflatoxin and fumonisin contamination levels. American Journal of Plant Sciences 3: 1341-1354. https:// doi.org/10.4236/ajps.2012.310162

Abbas, H.K., Wilkinson, J.R., Zablotowicz, R.M., Accinelli, C., Abel, C.A., Bruns, H.A. and Weaver, M.A., 2009. Ecology of Aspergillus flavus, regulation of aflatoxin production, and management strategies to reduce aflatoxin contamination of corn. Toxin Reviews 28: 142-153. https://doi.org/10.1080/15569540903081590

ACDI/VOCA, 2017. AflaSTOP: Innovations in portable drying technologies. ACDI/VOCA, Washington, DC, USA. Available at: https://tinyurl.com/57ck38fm.

Afolabi, C.G., Bandyopadhyay, R., Leslie, J.F. and Ekpo, E.J., 2006. Effect of sorting on incidence and occurrence of fumonisins and Fusarium verticillioides on maize from Nigeria. Journal of Food Protection 69: 2019-2023. https://doi.org/10.4315/0362-028x-69.8.2019

Alam, M.A., Saha, C.K., Alam, M.M., Manir, M.R., Rana, M.M. and Rashid, M.M., 2020. BAU-STR dryer for rough rice dying at farmers and small trader's level in Bangladesh. Journal of Science, Technology and Environment Informatics 9: 629-638. https://doi. org/10.18801/jstei.090120.64 
Amaike, S. and Keller, N.P., 2011. Aspergillus flavus. Annual Review of Phytopathology 49: 107-133. https://doi.org/10.1146/annurevphyto-072910-095221

Anitha, S., Tsusaka, T.W., Njoroge, S.M.C., Kumwenda, N., Kachulu, L., Maruwo, J., Machinjiri, N., Botha, R., Msere, H.W., Masumba, J., Tavares, A., Heinrich, G.M., Siambi, M. and Okori, P., 2019. Knowledge, attitude and practice of malawian farmers on pre- and post-harvest crop management to mitigate aflatoxin contamination in groundnut, maize and sorghum-implication for behavioral change. Toxins 11: 716. https://doi.org/10.3390/toxins11120716

Ankenbauer, K.J. and Loheide, S.P., 2017. The effects of soil organic matter on soil water retention and plant water use in a meadow of the Sierra Nevada, CA. Hydrological Processes 31: 891-901. https:// doi.org/10.1002/hyp.11070

Anukul, N., Vangnai, K. and Mahakarnchanakul, W., 2013. Significance of regulation limits in mycotoxin contamination in Asia and risk management programs at the national level. Journal of Food and Drug Analysis 21: 227-241. https://doi.org/10.1016/j.jfda.2013.07.009

Ashley, R.O., 2021. Corn maturity and ensiling corn. North Dakota State University, Dickinson Research Extension Center report. Available at: https://www.ag.ndsu.edu/archive/dickinso/agronomy/ cornmaturity.htm

Atehnkeng, J., Ojiambo, P.S., Ikotun, T., Sikora, R.A., Cotty, P.J. and Bandyopadhyay, R., 2008. Evaluation of atoxigenic isolates of Aspergillus flavus as potential biocontrol agents for aflatoxin in maize. Food Additives and Contaminants Part A 25: 1264-1271. https://doi.org/10.1080/02652030802112635

Azziz-Baumgartner, E., Lindblade, K., Gieseker, K., Rogers, H.S., Kieszak, S., Njapau, H., Schleicher, R., McCoy, L.F., Misore, A., DeCock, K., Rubin, C., Slutsker, L. and Aflatoxin Investigative, G., 2005. Case-control study of an acute aflatoxicosis outbreak, Kenya, 2004. Environmental Health Perspectives 113: 1779-1783. https:// doi.org/10.1289/ehp.8384

Balconi, C., Berardo, N., Locatelli, S., Lanzanova, C., Torri, A. and Redaelli, R., 2014. Evaluation of ear rot (Fusarium verticillioides) resistance and fumonisin accumulation in Italian maize inbred lines. Phytopathology 53: 14-26.

Bandyopadhyay, R., Ortega-Beltran, A., Akande, A., Mutegi, C., Atehnkeng, J., Kaptoge, L., Senghor, A.L., Adhikari, B.N. and Cotty, P.J., 2016. Biological control of aflatoxins in Africa: current status and potential challenges in the face of climate change. World Mycotoxin Journal 9: 771-789. https://doi.org/10.3920/wmj2016.2130

Bankole, S.A., Ogunsanwo, B.M. and Mabekoje, O.O., 2004. Natural occurrence of moulds and aflatoxin $B_{1}$ in melon seeds from markets in Nigeria. Food and Chemical Toxicology 42: 1309-1314. https:// doi.org/10.1016/j.fct.2004.03.015

Bari, Q.H., Mahbub Hassan, K. and Haque, R., 2012. Scenario of solid waste reuse in Khulna city of Bangladesh. Waste Management 32: 2526-2534. https://doi.org/10.1016/j.wasman.2012.07.001

Battilani, P., Toscano, P., Van der Fels-Klerx, H.J., Moretti, A., Camardo Leggieri, M., Brera, C., Rortais, A., Goumperis, T. and Robinson, T., 2016. Aflatoxin $B_{1}$ contamination in maize in Europe increases due to climate change. Scientific Reports 6: 24328. https://doi. org/10.1038/srep24328
Bauchet, J., Prieto, S. and Ricker-Gilbert, J., 2020. Improved drying and storage practices that reduce aflatoxins in stored maize: experimental evidence from smallholders in Senegal. American Journal of Agricultural Economics 103: 296-316. https://doi. org/10.1111/ajae.12106

Ben, D.C., Liem, P.V., Dao, N.T., Gummert, M. and Rickman, J.F., 2009. Effect of hermetic storage in the super bag on seed quality and milled rice quality of different varieties in Bac Lieu, Vietnam. International Rice Research Notes 31. https://doi.org/10.3860/irrn.v31i2.1138

Benkerroum, N., 2020. Aflatoxins: Producing-Molds, Structure, Health Issues and Incidence in Southeast Asian and Sub-Saharan African Countries. International Journal of Environmental Research and Public Health 17: 1215.

Blandino, M., Reyneri, A. and Vanara, F., 2008. Effect of plant density on toxigenic fungal infection and mycotoxin contamination of maize kernels. Field Crops Research 106: 234-241. https://doi. org/10.1016/j.fcr.2007.12.004

Blandino, M., Scarpino, V., Giordano, D., Sulyok, M., Krska, R., Vanara, F. and Reyneri, A., 2017. Impact of sowing time, hybrid and environmental conditions on the contamination of maize by emerging mycotoxins and fungal metabolites. Italian Journal of Agronomy 12: 215-224. https://doi.org/10.4081/ija.2017.928

Boedeker, W., Watts, M., Clausing, P. and Marquez, E., 2020. The global distribution of acute unintentional pesticide poisoning: estimations based on a systematic review. BMC Public Health 20: 1875. https:// doi.org/10.1186/s12889-020-09939-0

Boken, V.K., Hoogenboom†, G., Williams, J.H., Diarra, B., Dione, S. and Easson, G.L., 2010. Monitoring peanut contamination in Mali (Africa) using AVHRR satellite data and a crop simulation model. International Journal of Remote Sensing 29: 117-129. https://doi. org/10.1080/01431160701264250

Borgemeister, C., Adda, C., Sétamou, M., Hell, K., Djomamou, B., Markham, R.H. and Cardwell, K.F., 1998. Timing of harvest in maize: effects on post harvest losses due to insects and fungi in central Benin, with particular reference to Prostephanus truncatus (Horn) (Coleoptera: Bostrichidae). Agriculture, Ecosystems and Environment 69: 233-242. https://doi.org/10.1016/S01678809(98)00109-1

Brown, R.L., Chen, Z.-Y., Menkir, A. and Cleveland, T.E., 2003. Using biotechnology to enhance host resistance to aflatoxin contamination of corn. African Journal of Biotechnology 2: 557-562. https://doi. org/10.5897/ajb2003.000-1107

Brown, R.L., Menkir, A., Chen, Z.Y., Bhatnagar, D., Yu, J., Yao, H. and Cleveland, T.E., 2013. Breeding aflatoxin-resistant maize lines using recent advances in technologies - a review. Food Additives and Contaminants. Part A 30: 1382-1391. https://doi.org/10.1080 /19440049.2013.812808

Bruns, H.A., 2003. Controlling aflatoxin and fumonisin in maize by crop management. Journal of Toxicology - Toxin Reviews 22: 153173. https://doi.org/10.1081/txr-120024090

Bryden, W.L., 2012. Mycotoxin contamination of the feed supply chain: implications for animal productivity and feed security. Animal Feed Science and Technology 173: 134-158. https://doi.org/10.1016/j. anifeedsci.2011.12.014 
Bunnel, D. and Harvey, J., 2020. A path to safer food: the post-harvest loss innovation lab works to identify and mitigate mycotoxins. Agrilinks, 20 April 2020. Available at: https://tinyurl.com/44ths4jt. Catholic Relief Services, 2018. Aflatoxin management for smallholder farmers of maize and groundnuts: Practices and technologies for detection and prevention. Catholic Relief Services, Baltimore, MD, USA. Available at: https://tinyurl.com/334k2wuf.

Chauhan, Y., Wright, G. and Rachaputi, N.C., 2008. Modelling climatic risks of aflatoxin contamination in maize. Australian Journal of Experimental Agriculture 48: 358-366. https://doi.org/10.1071/ EA06101

Chen, Z.Y., Brown, R.L., Cleveland, T.E., Damann, K.F. and Russin, J.S., 2001. Comparison of constitutive and inducible maize kernel proteins of genotypes resistant or susceptible to aflatoxin production. Journal of Food Protection 64: 1785-1792. https://doi. org/10.4315/0362-028x-64.11.1785

Chulze, S.N., 2010. Strategies to reduce mycotoxin levels in maize during storage: a review. Food Additives and Contaminants Part A 27: 651-657. https://doi.org/10.1080/19440040903573032

Clements, M.J. and White, D.G., 2008. Identifying sources of resistance to aflatoxin and fumonisin contamination in corn grain. Journal of Toxicology - Toxin Reviews 23: 381-396. https://doi.org/10.1081/ txr-200027865

Cleveland, T.E., Dowd, P.F., Desjardins, A.E., Bhatnagar, D. and Cotty, P.J., 2003. United States Department of Agriculture-Agricultural Research Service research on pre-harvest prevention of mycotoxins and mycotoxigenic fungi in US crops. Pest Management Science 59: 629-642. https://doi.org/10.1002/ps.724

Cotty, P.J. and Bhatnagar, D., 1994. Variability among atoxigenic Aspergillus flavus strains in ability to prevent aflatoxin contamination and production of aflatoxin biosynthetic pathway enzymes. Applied and Environmental Microbiology 60: 2248-2251. https://doi.org/10.1128/aem.60.7.2248-2251.1994

Cotty, P.J. and Jaime-Garcia, R., 2007. Influences of climate on aflatoxin producing fungi and aflatoxin contamination. International Journal of Food Microbiology 119: 109-115. https://doi.org/10.1016/j. ijfoodmicro.2007.07.060

Council for Agricultural Science and Technology (CAST), 2003. Mycotoxins: risks in plant, animal and human systems. Task force report No. 139. Ames, IA, USA.

Daniel, J.H., Lewis, L.W., Redwood, Y.A., Kieszak, S., Breiman, R.F., Flanders, W.D., Bell, C., Mwihia, J., Ogana, G., Likimani, S., Straetemans, M. and McGeehin, M.A., 2011. Comprehensive assessment of maize aflatoxin levels in Eastern Kenya, 2005-2007. Environmental Health Perspectives 119: 1794-1799. https://doi. org/10.1289/ehp.1003044

Demissie, N., 2018. A review of aflatoxin: occurrence, prevention, and gaps in both food and feed safety. Novel Techniques in Nutrition and Food Science 1: 190-197. https://doi.org/10.31031/ ntnf.2018.01.000511

Diaz-Zorita, M., 2000. Effect of deep-tillage and nitrogen fertilization interactions on dryland corn (Zea mays L.) productivity. Soil Tillage Research 54: 11-19. https://doi.org/10.1016/s0167-1987(99)00100-2
Diener, U.L., Cole, R.J., Sanders, T.H., Payne, G.A., Lee, L.S. and Klich, M.A., 1987. Epidemiology of aflatoxin formation by Aspergillus flavus. Annual Review of Phytopathology 25: 249-270. https://doi. org/10.1146/annurev.py.25.090187.001341

Dovenyi-Nagy, T., Racz, C., Molnar, K., Bako, K., Szlama, Z., Jozwiak, A., Farkas, Z., Pocsi, I. and Dobos, A.C., 2020. Pre-harvest modelling and mitigation of aflatoxins in maize in a changing climatic environment - a review. Toxins 12: 768. https://doi.org/10.3390/ toxins 12120768

Dowd, P.F., 2003. Insect management to facilitate preharvest mycotoxin management. Journal of Toxicology - Toxin Reviews 22: 327-350. https://doi.org/10.1081/txr-120024097

Eeckhout, M., Landschoot, S., Deschuyffeleer, N., Laethauwer, S.D. and Haesaert, G., 2013. Guidelines for prevention and control of mould growth and mycotoxin production in cereals. MycoHunt, Ghent, Belgium. Available at: https://tinyurl.com/afm9v7cj.

Ehrlich, K.C., 2014. Non-aflatoxigenic Aspergillus flavus to prevent aflatoxin contamination in crops: advantages and limitations. Frontiers in Microbiology 5: 50. https://doi.org/10.3389/fmicb.2014.00050

Erdogan, A., 2004. The aflatoxin contamination of some pepper types sold in Turkey. Chemosphere 56: 321-325. https://doi.org/10.1016/j. chemosphere.2004.02.020

Fandohan, P., Zoumenou, D., Hounhouigan, D.J., Marasas, W.F., Wingfield, M.J. and Hell, K., 2005. Fate of aflatoxins and fumonisins during the processing of maize into food products in Benin. International Journal of Food Microbiology 98: 249-259. https:// doi.org/10.1016/j.ijfoodmicro.2004.07.007

Ferrigo, D., Mondin, M., Scopel, C., Dal Maso, E., Stefenatti, M., Raiola, A. and Causin, R., 2019. Effects of a prothioconazole- and tebuconazole-based fungicide on Aspergillus flavus development under laboratory and field conditions. European Journal of Plant Pathology 155: 151-161. https://doi.org/10.1007/s10658-019-017574

Food and Agriculture Organization of the United Nations (FAO), 2003. Development of a framework for good agricultural practices. COAG/2003/6. FAO, Rome, Italy. Available at: https://tinyurl. com/ha6r282y.

Food and Agriculture Organization of the United Nations (FAO), 2004. Code of practice for the prevention and reduction of aflatoxin contamination in peanuts. CAC/RCP 55-2004. FAO, Rome, Italy. Available at: https://tinyurl.com/b75jdc53.

Hawkins, L.K., Windham, G.L. and Williams, W.P., 2005. Effect of different postharvest drying temperatures on Aspergillus flavus survival and aflatoxin content in five maize hybrids. Journal of Food Protection 68: 1521-1524. https://doi.org/10.4315/0362028x-68.7.1521

Hell, K. and Mutegi, C., 2011. Aflatoxin control and prevention strategies in key crops of Sub-Saharan Africa. African Journal of Microbiology Research 5: 459-466.

Hell, K., Cardwell, K.F., Setamou, M. and Poehling, H., 2000. The influence of storage practices on aflatoxin contamination in maize in four agroecological zones of Benin, west Africa. Journal of Stored Products Research 36: 365-382. https://doi.org/10.1016/s0022$474 x(99) 00056-9$ 
Hell, K., Fandohan, P., Bandyopadhyay, R., Cardwell, K., Kiewnick, S., Sikora, R. and Cotty, P., 2008. Pre- and postharvest management of aflatoxin in maize: an African perspective. In: Leslie, J.F., Bandyopadhyay, R. and Visconti, A. (eds.) Mycotoxins: detection methods, management, public health and agricultural trade. CABI, Wallingford, UK, pp. 219-230. https://doi. org/10.1079/9781845930820.0219

Hell, K., Mutegi, C. and Fandohan, P., 2011. Aflatoxin control and prevention strategies in maize for Sub-Saharan Africa. Julius Kuhn Archiv 425: 534-541. https://doi.org/10.5073/jka.2010.425.388

Higley, L.G. and Pedigo, L.P., 1993. Economic injury level concepts and their use in sustaining environmental quality. Agriculture, Ecosystems and Environment 46: 233-243. https://doi. org/10.1016/0167-8809(93)90027-M

Hoffmann, V. and Jones, K.M., 2018. Improving food safety on the farm: experimental evidence from Kenya on agricultural incentives and subsidies as public health investments. IFPRI discussion papers. IFPRI, Washington, DC, USA. Available at: https://tinyurl. com/6cv9tcju.

Hoffmann, V. and Moser, C., 2017. You get what you pay for: the link between price and food safety in Kenya. Agricultural Economics 48: 449-458. https://doi.org/10.1111/agec.12346

Horn, B.W., 2003. Ecology and population biology of aflatoxigenic fungi in soil. Journal of Toxicology - Toxin Reviews 22: 351-379.

IIRR and ACT, 2005. Conservation agriculture: A manual for farmers and extension workers in Africa. International Institute of Rural Reconstruction, Nairobi, Kenya/African Conservation Tillage Network, Harare, Zimbabwe. Available at: https://tinyurl.com/7theb3kh

International Crops Research Institute for the Semi-Arid Tropics (ICRISAT), 2016. How to reduce aflatoxin contamination in groundnuts and maize a guide for extension workers. International Crops Research Institute for the Semi-Arid Tropics, Patancheru, India. Available at: https://tinyurl.com/cerm5vm7.

Jaffee, S., Henson, S., Unnevehr, L., Grace, D. and Cassou, E., 2018. Evidence on the burden of unsafe food in low- and middle-income countries. In: Unnevehr, L., Jaffee, S., Henson, S., Grace, D. and Cassou, E. (eds.) The safe food imperative: accelerating progress in low- and middle-income countries. World Bank, Washington, DC, USA, pp. 27-67. https://doi.org/10.1596/978-1-4648-1345-0_ch2

Jaime-García, R. and Cotty, P.J., 2006. Crop rotation influences aflatoxin producing potential of Aspergillus communities in south Texas. In: 2006 Beltwide Cotton Conferences, San Antonio, Texas, January 3-6, 2006, pp. 60-64.

Jirak-Peterson, J.C. and Esker, P.D., 2011. Tillage, crop rotation, and hybrid effects on residue and corn anthracnose occurrence in Wisconsin. Plant Disease 95: 601-610. https://doi.org/10.1094/ PDIS-11-10-0837

Joutsjoki, V.V. and Korhonen, H.J., 2021. Management strategies for aflatoxin risk mitigation in maize, dairy feeds and milk value chains - case study Kenya. Food Quality and Safety 5: fyab005. https:// doi.org/10.1093/fqsafe/fyab005

Kaaya, A.N. and Kyamuhangire, W., 2006. The effect of storage time and agroecological zone on mould incidence and aflatoxin contamination of maize from traders in Uganda. International Journal of Food Microbiology 110: 217-223. https://doi. org/10.1016/j.ijfoodmicro.2006.04.004
Kaaya, A.N., Kyamuhangire, W. and Kyamanywa, S., 2006. Factors affecting aflatoxin contamination of harvested maize in the three agroecological zones of Uganda. Journal of Applied Sciences 6: 2401-2407. https://doi.org/10.3923/jas.2006.2401.2407

Kaaya, A.N., Warren, H.L., Kyamanywa, S. and Kyamuhangire, W., 2005. The effect of delayed harvest on moisture content, insect damage, moulds and aflatoxin contamination of maize in Mayuge district of Uganda. Journal of the Science of Food and Agriculture 85: 2595-2599. https://doi.org/10.1002/jsfa.2313

Kagot, V., Okoth, S., De Boevre, M. and De Saeger, S., 2019. Biocontrol of Aspergillus and Fusarium mycotoxins in Africa: benefits and limitations. Toxins 11: 109. https://doi.org/10.3390/toxins11020109

Kamala, A., Kimanya, M., De Meulenaer, B., Kolsteren, P., Jacxsens, L., Haesaert, G., Kilango, K., Magoha, H., Tiisekwa, B. and Lachat, C., 2018. Post-harvest interventions decrease aflatoxin and fumonisin contamination in maize and subsequent dietary exposure in Tanzanian infants: a cluster randomised-controlled trial. World Mycotoxin Journal 11: 447-458. https://doi.org/10.3920/ wmj2017.2234

Kamau, T., Vyas, H. and Vitswamba, E., 2018. Technologies to mitigate aflatoxin. Engineering for Change, 12 November 2018. Available at: https://tinyurl.com/4janu9fp.

Keyser, J.C. and Sela, S., 2020. Innovations in food trade rethinking aflatoxin management in east Africa. International Bank for Reconstruction and Development/The World Bank, Washington, DC, USA. Available at: https://tinyurl.com/3tmfz42p.

Khlangwiset, P. and Wu, F., 2010. Costs and efficacy of public health interventions to reduce aflatoxin-induced human disease. Food Additives and Contaminants Part A 27: 998-1014. https://doi. org/10.1080/19440041003677475

Kumar, P., Mahato, D.K., Kamle, M., Mohanta, T.K. and Kang, S.G., 2016. Aflatoxins: a global concern for food safety, human health and their management. Frontiers in Microbiology 7: 2170. https:// doi.org/10.3389/fmicb.2016.02170

Lewis, L., Onsongo, M., Njapau, H., Schurz-Rogers, H., Luber, G., Kieszak, S., Nyamongo, J., Backer, L., Dahiye, A.M., Misore, A., DeCock, K., Rubin, C. and the Kenya Aflatoxicosis Investigation Group, 2005. Aflatoxin contamination of commercial maize products during an outbreak of acute aflatoxicosis in eastern and central Kenya. Environmental Health Perspectives 113: 1763-1767. https://doi.org/10.1289/ehp.7998

Liebman, M. and Dyck, E., 1993. Crop rotation and intercropping strategies for weed management. Ecological Applications 3: 92-122. https://doi.org/10.2307/1941795

Liu, Y., Galani Yamdeu, J.H., Gong, Y.Y. and Orfila, C., 2020. A review of postharvest approaches to reduce fungal and mycotoxin contamination of foods. Comprehensive Reviews in Food Science and Food Safety 19: 1521-1560. https://doi.org/10.1111/15414337.12562

Liu, Z., Zhang, G., Zhang, Y., Jin, Q., Zhao, J. and Li, J., 2016. Factors controlling mycotoxin contamination in maize and food in the Hebei province, China. Agronomy for Sustainable Development 36: 39. 
Logrieco, A., Battilani, P., Leggieri, M.C., Jiang, Y., Haesaert, G., Lanubile, A., Mahuku, G., Mesterhazy, A., Ortega-Beltran, A., Pasti, M., Smeu, I., Torres, A., Xu, J. and Munkvold, G., 2021. Perspectives on global mycotoxin issues and management from the Mycokey maize working group. Plant Disease 105: 525-537. https://doi. org/10.1094/PDIS-06-20-1322-FE

Magagnoli, S., Lanzoni, A., Masetti, A., Depalo, L., Albertini, M., Ferrari, R., Spadola, G., Degola, F., Restivo, F.M. and Burgio, G., 2021. Sustainability of strategies for Ostrinia nubilalis management in Northern Italy: Potential impact on beneficial arthropods and aflatoxin contamination in years with different meteorological conditions. Crop Protection 142: 105529. https://doi.org/10.1016/j. cropro.2020.105529

Magan, N. and Aldred, D., 2007. Post-harvest control strategies: minimizing mycotoxins in the food chain. International Journal of Food Microbiology 119: 131-139. https://doi.org/10.1016/j. ijfoodmicro.2007.07.034

Mahuku, G., Nzioki, H.S., Mutegi, C., Kanampiu, F., Narrod, C. and Makumbi, D., 2019. Pre-harvest management is a critical practice for minimizing aflatoxin contamination of maize. Food Control 96: 219-226. https://doi.org/10.1016/j.foodcont.2018.08.032

Manu, N., Opit, G.P., Osekre, E.A., Arthur, F.H., Mbata, G., Armstrong, P., Danso, J.K., McNeill, S.G. and Campbell, J.F., 2019. Moisture content, insect pest infestation and mycotoxin levels of maize in markets in the northern region of Ghana. Journal of Stored Products Research 80: 10-20. https://doi.org/10.1016/j.jspr.2018.10.007

Massomo, S.M.S., 2020. Aspergillus flavus and aflatoxin contamination in the maize value chain and what needs to be done in Tanzania. Scientific African 10: e00606. https://doi.org/10.1016/j.sciaf.2020. e00606

Mateo, E.M., Gómez, J.V., Gimeno-Adelantado, J.V., Romera, D., Mateo-Castro, R. and Jiménez, M., 2017. Assessment of azole fungicides as a tool to control growth of Aspergillus flavus and aflatoxin $B_{1}$ and $B_{2}$ production in maize. Food Additives and Contaminants Part A 34: 1039-1051. https://doi.org/10.1080/19 440049.2017.1310400

Matocha, J.E. and Richardson, M., 1990. Crop rotations, reduced tillage and $\mathrm{n}$ fertilization effects on corn yields and aflatoxin levels. Agronomy Journal 83: 979-985. https://doi.org/10.1.1.543.5918

McMillian, W.W., Wilson, D.M. and Widstrom, N.W., 1985. Aflatoxin contamination of preharvest corn in Georgia: a six-year study of insect damage and visible Aspergillus flavus. Journal of Environmental Quality 14: 200-202. https://doi.org/10.2134/ jeq1985.00472425001400020010x

Medina, A., Rodriguez, A. and Magan, N., 2014. Effect of climate change on Aspergillus flavus and aflatoxin $\mathrm{B}_{1}$ production. Frontiers in Microbiology 5: 348. https://doi.org/10.3389/fmicb.2014.00348

Mejía, D., 2003. Maize: post-harvest operation. INPhO - Post-harvest Compendium. FAO, Rome, Italy. Available at: https://tinyurl. com/3pp6bsnf.

Menkir, A., Brown, R., Bandyopadhyay, R. and Cleveland, T., 2008. registration of six tropical maize germplasm lines with resistance to aflatoxin contamination. Journal of Plant Registrations 2: 246-250. https://doi.org/10.3198/jpr2008.01.0028crg
Monda, E., Masanga, J. and Alakonya, A., 2020. Variation in occurrence and aflatoxigenicity of Aspergillus flavus from two climatically varied regions in Kenya. Toxins 12: 34. https://doi.org/10.3390/ toxins 12010034

Moswetsi, G., Fanadzo, M. and Ncube, B., 2017. Cropping systems and agronomic management practices in smallholder farms in South Africa: constraints, challenges and opportunities. Journal of Agronomy 16: 51-64. https://doi.org/10.3923/ja.2017.51.64

Murdock, L.L., Shade, R.E., Kitch. L.W., Ntoukam, G., LowenbergDeboer, J., Huesing, J.E., Moar, W., Chambliss, O.L., Endondo, C. and Wolfson, J.L, 1997. Postharvest storage of cowpea in sub-Saharan Africa. In: Singh, B.B., Mohan Raj, D.R., Dashiell, K.E. and Jackai, L.E.N. (eds.) Advances in cowpea research. Sayce Publishing, Devon, UK, pp. 302-312.

Mutiga, S.K., Mushongi, A.A. and Kangéthe, E.K., 2019. Enhancing food safety through adoption of long-term technical advisory, financial, and storage support services in maize growing areas of East Africa. Sustainability 11: 2827. https://doi.org/10.3390/su11102827

Mutiga, S.K., Were, V., Hoffmann, V., Harvey, J.W., Milgroom, M.G. and Nelson, R.J., 2014. Extent and drivers of mycotoxin contamination: Inferences from a survey of Kenyan maize mills. Phytopathology 104: 1221-1231.

Mutunga, E.J., Ndungu, C. and Muendo, P., 2017. Smallholder farmers' perceptions and adaptations to climate change and variability in Kitui County, Kenya. Journal of Earth Science and Climate Change 8: 389. https://doi.org/10.4172/2157-7617.1000389

Ndemera, M., Landschoot, S., Boevre, M., Nyanga, L. and Saeger, S., 2018. Effect of agronomic practices and weather conditions on mycotoxins in maize: a case study of subsistence farming households in Zimbabwe. World Mycotoxin Journal 11: 421-436. https://doi. org/10.3920/WMJ2017.2227

Njeru, N.K., Midega, C.A.O., Muthomi, J.W., Wagacha, J.M. and Khan, Z.R., 2019. Influence of socio-economic and agronomic factors on aflatoxin and fumonisin contamination of maize in western Kenya. Food Science and Nutrition 7: 2291-2301. https://doi.org/10.1002/ fsn 3.1070

Nyang'au, J.O., Mohamed, J.H., Mango, N., Makate, C. and Wangeci, A.N., 2021. Smallholder farmers' perception of climate change and adoption of climate smart agriculture practices in Masaba South sub-county, Kisii, Kenya. Heliyon 7: e06789. https://doi. org/10.1016/j.heliyon.2021.e06789

Olanya, O.M., Hoyos, G.M., Tiffany, L.H. and McGee, D.C., 1997. Waste corn as a point source of inoculum for Aspergillus flavus in the corn agroecosystem. Plant Disease 81: 576-581. https://doi. org/10.1094/PDIS.1997.81.6.576

Parimi, M., Buelter, J., Thanugundla, V., Condoor, S., Parkar, N., Danon, S. and King, W., 2018. Correction to: feasibility and validity of printing 3D heart models from rotational angiography. Pediatric Cardiology 39: 659. https://doi.org/10.1007/s00246-018-1863-2

Park, D.L., 2002. Effect of processing on aflatoxin. In: DeVries, J.W., Trucksess, M.W. and Jackson, L.S. (eds.) Mycotoxins and food safety. Advances in Experimental Medicine and Biology 504. Springer, Berlin, Germany, pp. 173-179. https://doi.org/10.1007/978-1-46150629-4_17 
Pascale, M., Logrieco, A., Graeber, M., Hirschberger, M., Reichel, M., Lippolis, V., De Girolamo, A., Lattanzio, V. and Slettengren, K., 2020. Aflatoxin reduction in maize by industrial-scale cleaning solutions. Toxins 12: 331. https://doi.org/10.3390/toxins12050331 Paudyal, S., Opit, G.P., Osekre, E.A., Arthur, F.H., Bingham, G.V., Payton, M.E., Danso, J.K., Manu, N. and Nsiah, E.P., 2017. Field evaluation of the long-lasting treated storage bag, deltamethrin incorporated, (ZeroFly ${ }^{\oplus}$ Storage Bag) as a barrier to insect pest infestation. Journal of Stored Products Research 70: 44-52. https:// doi.org/10.1016/j.jspr.2016.11.003

Philippine National Standards, 2008. Code of practice for the prevention and reduction of aflatoxin contamination in corn. Available at: https://tinyurl.com/3c9u9vr3.

Pitt, J.I., 2019. The pros and cons of using biocontrol by competitive exclusion as a means for reducing aflatoxin in maize in Africa. World Mycotoxin Journal 12: 103-112. https://doi.org/10.3920/ wmj2018.2410

Post Disaster Needs Assessment (PDNA), 2012. Kenya post-disaster needs assessment 2008-2011 drought report. European Union/ United Nations/Government of Kenya/World Bank. Available at: http://www.gfdrr.org/sites/gfdrr/files/Kenya_PDNA_Final.pdf.

Probst, C., Bandyopadhyay, R. and Cotty, P.J., 2014. Diversity of aflatoxin-producing fungi and their impact on food safety in subSaharan Africa. International Journal of Food Microbiology 174: 113-122. https://doi.org/10.1016/j.ijfoodmicro.2013.12.010

Rapsomanikis, G., 2015. The economic lives of smallholder farmers. An analysis based on household data from nine countries. FAO, Rome, Italy. https://doi.org/10.13140/RG.2.1.3223.9440

Sangoi, L., Gracietti, M.A., Rampazzo, C. and Bianchetti, P., 2002. Response of Brazilian maize hybrids from different eras to changes in plant density. Field Crops Research 79: 39-51. https://doi. org/10.1016/S0378-4290(02)00124-7

Semple, R.L., Firo, A.S., Hicks, P.A. and Lozare, J.V., 1989. Mycotoxin prevention and control in food grains. UNDP/FAO/REGNET and the ASEAN grain postharvest program, Bangkok, Thailand. Available at: https://tinyurl.com/2m4a6c8s.

Sétamou, M., Cardwell, K.F., Schulthess, F. and Hell, K., 1997. Aspergillus flavus infection and aflatoxin contamination of preharvest maize in Benin. Plant Disease 81: 1323-1327. https:// doi.org/10.1094/PDIS.1997.81.11.1323

Sétamou, M., Cardwell, K.F., Schulthess, F. and Hell, K., 1998. Effect of insect damage to maize ears, with special reference to Mussidia nigrivenella (Lepidoptera: Pyralidae), on Aspergillus flavus (Deuteromycetes: Monoliales) infection and aflatoxin production in maize before harvest in the Republic of Benin. Journal of Economic Entomology 91: 433-438. https://doi.org/10.1093/jee/91.2.433

Shee, A., Mayanja, S., Simba, E., Stathers, T., Bechoff, A. and Bennett, B., 2019. Determinants of postharvest losses along smallholder producers maize and sweet potato value chains: an ordered Probit analysis. Food Security 11: 1101-1120. https://doi.org/10.1007/ s12571-019-00949-4

Shepherd, A., 1999. A guide to maize marketing for extension officers. Food and Agriculture Organization of the United Nations, Rome Italy. Available at: https://tinyurl.com/uwnehm9s.
Shi, H., Stroshine, R.L. and Ileleji, K., 2014. Aflatoxin reduction in corn by cleaning and sorting, 2014 Montreal, Quebec, Canada, July 13 - July 16, 2014. ASABE, St. Joseph, MI, USA. ASABE Paper No. 141890901. https://doi.org/10.13031/aim.20141890901

Smith, M.S. and Riley, T.J., 1992. Direct and interactive effects of planting date, irrigation, and corn earworm (Lepidoptera: Noctuidae) damage on aflatoxin production in preharvest field corn. Journal of Economic Entomology 85: 998-1106. https://doi.org/10.1093/ jee/85.3.998

Soni, P., Gangurde, S.S., Ortega-Beltran, A., Kumar, R., Parmar, S., Sudini, H.K., Lei, Y., Ni, X., Huai, D., Fountain, J.C., Njoroge, S., Mahuku, G., Radhakrishnan, T., Zhuang, W., Guo, B., Liao, B., Singam, P., Pandey, M.K., Bandyopadhyay, R. and Varshney, R.K., 2020. Functional biology and molecular mechanisms of hostpathogen interactions for aflatoxin contamination in groundnut (Arachis hypogaea L.) and maize (Zea mays L.). Frontiers in Microbiology 11: 227. https://doi.org/10.3389/fmicb.2020.00227

Spanjer, M.C., 2019. Occurrence \& risk of aflatoxins in food and feed. In: Melton, L., Shahidi, F. and Varelis, P. (eds.) Encyclopedia of food chemistry. Elsevier, Amsterdam, the Netherlands, pp. 424-427. https://doi.org/10.1016/b978-0-08-100596-5.21804-0

Steinberg, G. and Gurr, S.J., 2020. Fungi, fungicide discovery and global food security. Fungal Genetics and Biology 144: 103476. https:// doi.org/10.1016/j.fgb.2020.103476

Strosnider, H., Azziz-Baumgartner, E., Banziger, M., Bhat, R.V., Breiman, R., Brune, M.-N., DeCock, K., Dilley, A., Groopman, J., Hell, K., Henry, S.H., Jeffers, D., Jolly, C., Jolly, P., Kibata, G.N., Lewis, L., Liu, X., Luber, G., McCoy, L., Mensah, P., Miraglia, M., Misore, A., Njapau, H., Ong, C.-N., Onsongo, M.T.K., Page, S.W., Park, D., Patel, M., Phillips, T., Pineiro, M., Pronczuk, J., Rogers, H.S., Rubin, C., Sabino, M., Schaafsma, A., Shephard, G., Stroka, J., Wild, C., Williams, J.T. and Wilson, D., 2006. Workgroup report: public health strategies for reducing aflatoxin exposure in developing countries. Environmental Health Perspectives 114: 1898-1903. https://doi. org/doi:10.1289/ehp.9302

Suleiman, R. and Rosentrater, K., 2015. Current maize production, postharvest losses and the risk of mycotoxins contamination in Tanzania. In: 2015 ASABE Annual International Meeting, ASABE, St. Joseph, MI, USA. Paper No. 152189434. https://doi.org/10.13031/ aim.20152189434

Sumner, P.E. and Lee, D., 2017. Reducing aflatoxin in corn during harvest and storage. University of Georgia Cooperative Extension Bulletin 1231: 1-6.

Thai Agriculture Standard, 2010. Good agricultural practices for maize. TAS 4402-2010. Available at: https://tinyurl.com/fzm8ux2b.

Thompson, J.F., Reid, M.S., Felix, L., Donis-Gonzalez, I., Mjawa, B. and Ambuko, J., 2017. DryCard - a low-cost dryness indicator for dried products. AIMS Agriculture and Food 2: 339-344. https:// doi.org/10.3934/agrfood.2017.4.339

Thornton, P.K. and Herrero, M., 2015. Adapting to climate change in the mixed crop and livestock farming systems in sub-Saharan Africa. Nature Climate Change 5: 830-836. https://doi.org/10.1038/ nclimate2754 
Tubajika, K.M., Mascagni, H.J., Jr., Damann, K.E. and Russin, J.S., 1999. Nitrogen fertilizer influence on aflatoxin contamination of corn in Louisiana. Journal of Agricultural and Food Chemistry 47: 5257-5260. https://doi.org/10.1021/jf990535f

Turner, P.C., Sylla, A., Gong, Y.Y., Diallo, M.S., Sutcliffe, A.E., Hall, A.J. and Wild, C.P., 2005. Reduction in exposure to carcinogenic aflatoxins by postharvest intervention measures in west Africa: a community-based intervention study. The Lancet 365: 1950-1956. https://doi.org/10.1016/S0140-6736(05)66661-5

Udoh, J.M., Cardwell, K.F. and Ikotun, T., 2000. Storage structures and aflatoxin content of maize in five agroecological zones of Nigeria. Journal of Stored Products Research 36: 187-201. https:// doi.org/10.1016/s0022-474x(99)00042-9

Udomkun, P., Wossen, T., Nabahungu, N.L., Mutegi, C., Vanlauwe, B. and Bandyopadhyay, R., 2018. Incidence and farmers' knowledge of aflatoxin contamination and control in Eastern Democratic Republic of Congo. Food Science and Nutrition 6: 1607-1620. https://doi. org $/ 10.1002 /$ fsn3.735

Unnevehr, L. and Grace, D., 2013. Aflatoxins: finding solutions for improved food safety. IFPRI 2020 Focus Brief 20. IFPRI, Washington, DC, USA. https://doi.org/10.2499/9780896296763

Van Egmond, H.P. and Jonker, M.A., 2008. Worldwide regulations on aflatoxins - the situation in 2002. Journal of Toxicology - Toxin Reviews 23: 273-293. https://doi.org/10.1081/txr-200027844

Walker, S., Jaime, R., Kagot, V. and Probst, C., 2018. Comparative effects of hermetic and traditional storage devices on maize grain: Mycotoxin development, insect infestation and grain quality. Journal of Stored Products Research 77: 34-44. https://doi.org/10.1016/j. jspr.2018.02.002
Wang, C., Xu, F., Baker, R.C., Pinjari, A., Bruckers, L., Zhao, Y., Stevenson, A. and Zhang, G., 2021. Fungi carried over in jute bags a smoking gun for aflatoxin contamination in the food supply chain. World Mycotoxin Journal 14: 155-163. https://doi.org/10.3920/ wmj2020.2619

Widstrom, N.W., 1979. The role of insects and other plant pests in aflatoxin contamination of corn, cotton, and peanuts - a review. Journal of Environmental Quality 8: 5-11. https://doi.org/10.2134/ jeq1979.00472425000800010002x

Wightwick, A., Walters, R., Allinson, G., Reichman, S. and Menzies, N., 2010. Environmental risks of fungicides used in horticultural production systems. In: C. Odile (ed.) Fungicides. Intech Open, London, UK, pp. 273-304. https://doi.org/10.5772/13032

Wild, C.P. and Gong, Y.Y., 2010. Mycotoxins and human disease: a largely ignored global health issue. Carcinogenesis 31: 71-82. https:// doi.org/10.1093/carcin/bgp264

Williams, S.B., Baributsa, D. and Woloshuk, C., 2014. Assessing Purdue Improved Crop Storage (PICS) bags to mitigate fungal growth and aflatoxin contamination. Journal of Stored Products Research 59: 190-196. https://doi.org/10.1016/j.jspr.2014.08.003

Windham, G.L., Williams, W.P. and Davis, F.M., 1999. Effects of the southwestern corn borer on Aspergillus flavus kernel infection and aflatoxin accumulation in maize hybrids. Plant Disease 83: 535-540.

Zhang, C., Wohlhueter, R. and Zhang, H., 2016. Genetically modified foods: A critical review of their promise and problems. Food Science and Human Wellness 5: 116-123. https://doi.org/https:// doi.org/10.1016/j.fshw.2016.04.002

Zuber, M.S., Calvert, O.H., Lillehoj, E.B. and Kwolek, W.F., 1976. Preharvest development of aflatoxin $\mathrm{B}_{1}$ in corn in the United States. Phytopathology 66: 1120-1121. 